\title{
Optimization of High Rate DAF Process for Removal of Algae in Water Treatment Plant
}

\author{
Woosik Jung, Hyun Je Oh \\ Environmental and Plant Engineering Research Institute, Korea Institute of Civil and Building Technology \\ Goyang, Gyeonggi, South Korea \\ woosik@kict.re.kr; hjoh@kict.re.kr
}

\begin{abstract}
In recent years there have been large increases in the hydraulic loading rates used to design dissolved air flotation (DAF) facilities for drinking water applications. High rate DAF processes are now available at loading rates of 20 to $40 \mathrm{~m} 3 / \mathrm{m} 2 \cdot \mathrm{h}$. This research evaluated dissolved air flotation as a separation method for algae and organic compounds from water treatment plants. During the service period of 2016. 5. to 2017. 6., DAF pilot plants (500 m3/day) process has shown a constantly sound performance for the treatment of raw water, yielding a significantly low level of turbidity (DAF treated water, $0.21 \sim 1.56 \mathrm{NTU}$ ). As a result of analyzing the algae cell counts in the influent source, it was expressed at 100-120 cells/mL. In DAF treated water, the removal efficient of algae cell counts was found to be up to $90 \%$. The stable turbidity and algae removal were confirmed by operating the high rate DAF process under the condition of the surface loading rate of $30 \mathrm{~m} 3 / \mathrm{m} 2 \cdot \mathrm{hr}$. The number of algae in the DAF treated water has been analyzed to be less than 100 cells $/ \mathrm{mL}$. These results indicated that the DAF process is effective in removing the algae.
\end{abstract}

Keywords: Algae, Surface Loading Rate, Dissolved Air Flotation, Decision Algorithm, Integrated Management System.

\section{Introduction}

Cyanobacteria (blue-green algae) have been identified worldwide, posing a significant risk to water supplies when they occur in reservoirs, lakes and rivers used as water sources, due to their ability to produce toxins - as well as taste and odor compounds - as secondary metabolites under particular conditions of growth. The occurrence of cyanobacteria (bluegreen algae) in reservoirs, lakes and rivers used as drinking water sources is a worldwide environmental health issue, due to the ability of some cyanobacterial streams to produce toxins, as well as taste and odour compounds, as secondary metabolites under particular conditions of growth. The most commonly occurring group of cyanobacterial hepatotoxins in freshwaters are microcystins and as a result of the increasing concern with their health implications the World Health Organisation [1] has set a provision alguideline-valuein drinking water of 1.0mg/L for microcystin-LR (MC-LR), one of the most toxic and usual microcystin variant. Microcystins are potentially produced by common genera of cyanobacteria, such as Microcystis, Planktothrix and Anabaena [2]. Microcystis are unicellular or colonial while Planktothrix and Anabaena are naturally occurring filamentous cyanobacteria. Algae also cause operational problems such as the blocking of filters, which reduce the using time of filter and increase the consumption of backwash water. Actually, many conventional water treatment plants combined by sedimentation in Korea have undergone serious operational problems due to the scum generated by algae floats [3].

Therefore, the more advanced and efficient techniques, that is the application of the DAF process (dissolved air flotation), have been introduced into the treatment process for reducing the algal load. Algal-rich waters have difficulties to be treated by sedimentation because of the characteristics of algae which has the tendency to float, its small size, low cell density and negative surface charge [4]. An alternative technique for the clarification of algal-rich waters is dissolved air flotation (DAF) [5]. The principle of sedimentation is based on removal of settleable floc particles by the process of gravity settling, while the principle of DAF is based on the removal of bubble-flocs agglomerates as air bubbles rise and contact with flocs in flotation tank. DAF process was not used in water treatment plants but wastewater treatment plants, so there was not much experience of using DAF for water treatment in Korea. However, it has been successfully applied in Korea to treat the raw water containing algae blooms. Primary clarification involves either sedimentation or flotation of flocculated water. Conventional drinking water treatment trains include coagulation $(C)$, flocculation $(F)$ and sedimentation (S). However, algal-rich waters especially important during a cyanobacterial bloom occurrence pose problems to 
sedimentation, due to the algae tendency to float, its small size, low cell density and negative surface charge. An alternative technique for the clarification of algal-rich waters is dissolved air flotation (DAF) [6]. As far as the DAF operating conditions are concerned, the effectiveness of the pressurized recycle system has been referred as crucial to the success and economy of the DAF process [5, 7]. DAF is generally more effective than sedimentation for treating algal-rich water.

This study evaluated several integration of a DAF combining with granular activated carbon (GAC). In order to select the best position of the GAC process and pilot plants experiments were performed using raw water, coagulated water and DAF treated water collected from YC-WPT.

\section{Materials and Methods \\ 2.1. Design of DAF Pilot Plant}

The overall layout of the DAF pilot plant $\left(500 \mathrm{~m}^{3} / \mathrm{d}\right)$ is illustrated in Figure 1 and Table 1 . The operation of the DAF pilot plant $\left(500 \mathrm{~m}^{3} / \mathrm{d}\right)$ consists of three different processes, those of pre-coagulation/flocculation, DAF process, and filtration with granular activated carbon (GAC). In order to optimize the coagulation efficiency, the DAF pilot plant (500 $\mathrm{m}^{3} / \mathrm{d}$ ) has two pump diffusion units consisting of mixing pump, jet spray nozzle, and chemical diffusers. The jet spray nozzle equipped in the raw water pipeline provides high intensity mixing by discharging between 3 and $5 \%$ of the total plant flow through the flash mix against the target plant, resulting in uniform and rapid distribution of coagulants into the raw water stream. Two types of operating modes strategically control these processes, as shown in Figure 2 . These operating modes are 1) Coagulation process, 2) DAF process, 3) GAC filtration. Among the various operating modes, the coagulation and DAF process modes are only used at the low $(<10 \mathrm{NTU})$ and common level $(<5 \mathrm{NTU})$ of turbidity in raw water. During the service period of 2015.06 .01 to 2015 . 06. 31, the DAF pilot plant $\left(500 \mathrm{~m}^{3} / \mathrm{d}\right)$ was operated with only two operating modes (Coagulation process and DAF process) to test the performance of the DAF plant, regardless of the raw water quality. The DAF pilot plant $\left(500 \mathrm{~m}^{3} / \mathrm{d}\right)$ was operated with the coagulation process and DAF process operating mode. Table 1 summarizes the information on the design and operating parameters of each process installed in the DAF pilot plant $\left(500 \mathrm{~m}^{3} / \mathrm{d}\right)$. The DAF pilot plant $\left(500 \mathrm{~m}^{3} / \mathrm{d}\right)$ has a total capacity of $680 \mathrm{~m}^{3} / \mathrm{d}$. Flotation basin was made $4,000 \mathrm{~mm}$ of height in order to implement the high rate $\left(30 \mathrm{~m}^{3} / \mathrm{m}^{2} \cdot \mathrm{h}\right)$ by varying the installation height of the tank was injured optimize the sludge scraper. In addition, a nozzle was constructed in two line due to the control the bubble generation. The lower perforated plate is installed to the occurrence to generate the flow of the bubble is formed the long remained an essential device for the high rate implementation. DAF system is designed to work processing capacity of $500 \mathrm{~m}^{3}$ according to the design criteria developed by the research process.

\subsection{Operation Conditions of DAF Pilot Plant}

The DAF pilot plant was installed in Y water purification plant in Yeongcheon, South Korea. The structure of the DAF pilot plant consists of raw water inlet piping, mixing process, coagulation process, flotation process, pressurized

flotation system and device control. The influent flow rate was $27 \mathrm{~m}^{3} / \mathrm{hr}$ maximum, and the coagulation process consisted of two stages and the retention time was designed to be 10 minutes each. The residence time of the flotation tank was about 20 minutes, and the screw type skimmer was designed to efficiently remove flotation sludge. In the case of the High Rate DAF pilot plant applied to this study, even if the residence time is designed to be smaller than the design standard of the water purification plant in the pretreatment study results, it is determined to be at least 10 minutes and 20 minutes in total. 


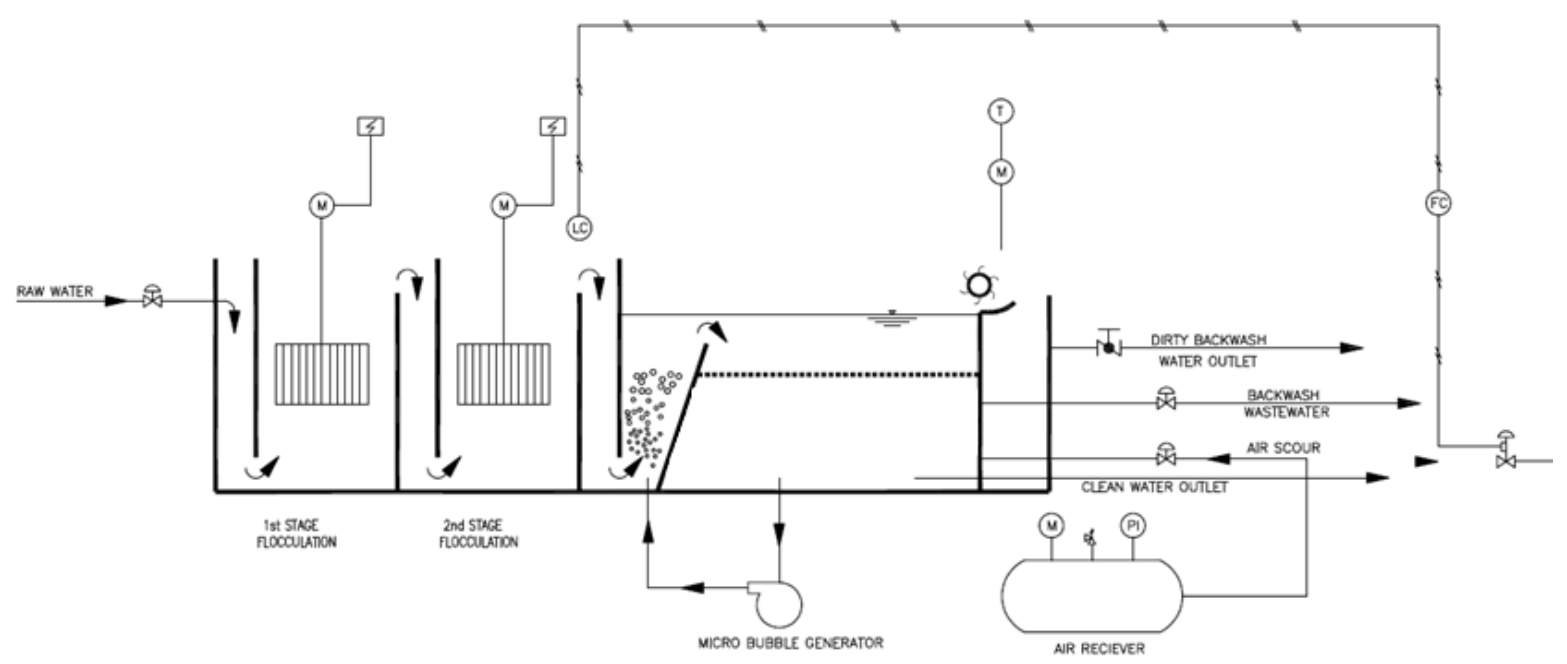

Fig. 1: Schematic Diagram of High Rate DAF Pilot Plant.

Table 1: Summary of the information on the design and operating parameters.

\begin{tabular}{|c|c|c|}
\hline Process & Contents & Condition \\
\hline \multirow{5}{*}{ General } & Flow rate & $500 \mathrm{~m}^{3} /$ day \\
\hline & Operating time & $24 \mathrm{hr} /$ day \\
\hline & $\mathrm{pH}$ & 7.5 \\
\hline & Turbidity & $5 \mathrm{NTU}$ \\
\hline & SS & $5 \sim 10 \mathrm{mg} / \mathrm{L}$ \\
\hline \multirow{4}{*}{ Coagulation } & Specific surface area & $3.6 \mathrm{~m}^{3}$ \\
\hline & Type & rectangle \\
\hline & Flow type & weir \\
\hline & HRT & $3.6 \times 60 / 20=10.8 \mathrm{~min}$ \\
\hline \multirow{4}{*}{ Flotation } & SS & $5 \sim 10 \mathrm{mg} / \mathrm{L}$ \\
\hline & HRT & $15 \sim 25 \mathrm{~min}$ \\
\hline & Loading rate & $\begin{array}{c}30 \mathrm{~m}^{3} / \mathrm{m}^{2} \bullet \mathrm{hr}\left(499 \mathrm{~L} / \mathrm{m}^{2} .\right. \\
\mathrm{min})\end{array}$ \\
\hline & Depth & $2.50 \sim 2.60 \mathrm{~m}$ \\
\hline \multirow{2}{*}{ Saturator } & Size & $0.3 \mathrm{D} \times 0.95 \mathrm{H}$ \\
\hline & Area & $0.077 \mathrm{~m}^{2}$ \\
\hline
\end{tabular}

\section{Results and Discussions}

\subsection{Optimization of Coagulant Dose for High Rate DAF Process}

The optimal coagulant dose experiments were conducted through the Jar-Test to obtain the optimal operation efficiency for the high rate DAF pilot plant $(500 \mathrm{~m} 3 / \mathrm{d})$. The coagulant used in the experiment was $10 \%$ PAC and the concentration was $0 \sim 25 \mathrm{mg} / \mathrm{L}$. The optimum concentration of coagulant and injection amount was selected through the Jar-Test. The coagulant used in the experiment was 10\% PAC, and the concentration was $0 \sim 25 \mathrm{mg} / \mathrm{L}$. The floc condition of the high rate DAF pilot plant for the selected coagulant injection concentration and the treated water quality were 
observed. Jar-test was carried out at $10 \%$ PAC concentration of coagulant in the range of $0 \sim 25 \mathrm{mg} / \mathrm{L}$. As a result, turbidity removal rate was $56 \sim 62 \%$ in concentration range of $10 \sim 25 \mathrm{mg} / \mathrm{L}$, Considering the operation cost, the injection concentration of $10 \mathrm{mg} / \mathrm{L}$ is considered to be the most optimal injection concentration. In the operation of DAF pilot plant, $10 \mathrm{mg} / \mathrm{L}$ of coagulant injection concentration derived from this experiment was applied.

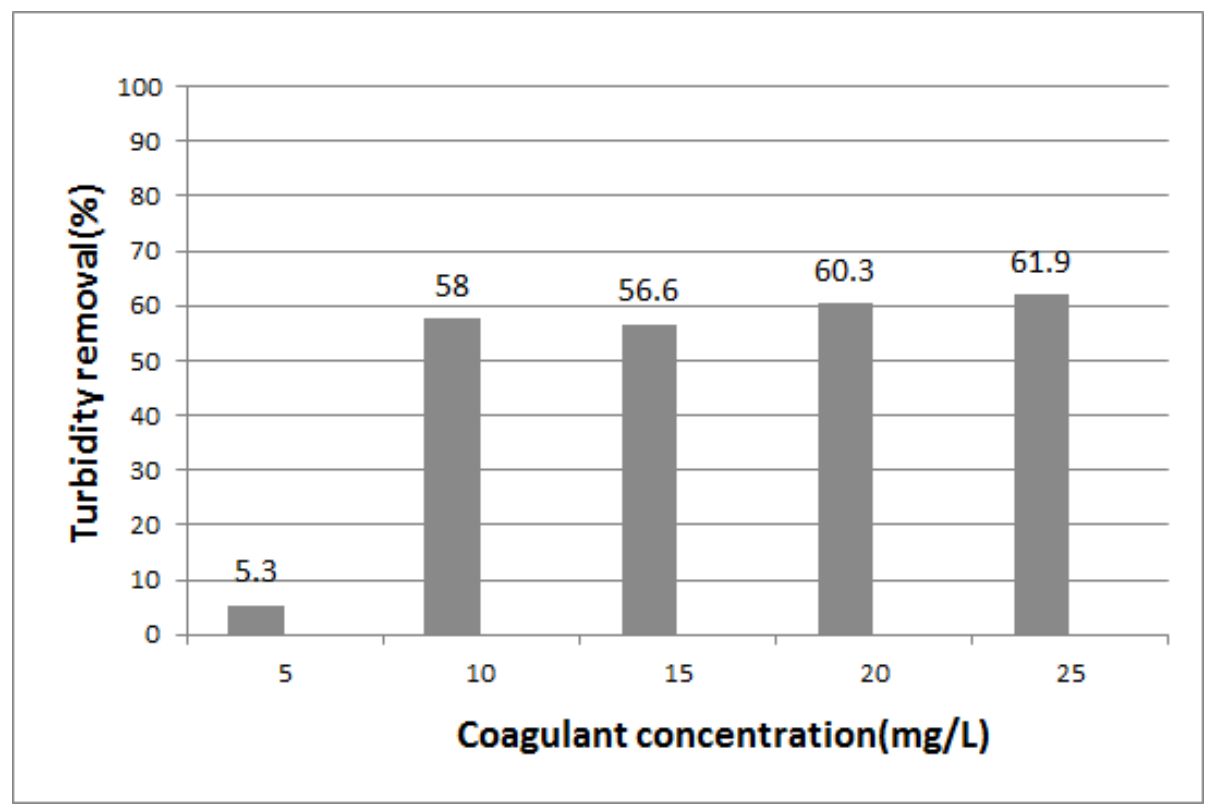

Fig. 2: Turbidity Removal Rate in High Rate DAF Pilot Plant by Coagulant Concentration.

\subsection{Operating Efficiency According to Saturator Water Level/Pressure Change}

Turbidity removal rate experiments were carried out in a high rate DAF pilot plant according to the water level and pressure changes in the Saturator through a pressurized floating system capable of automatic. The turbidity of DAF treated water at each water level was observed by setting the water level in the saturator range from 33 to $48 \mathrm{~mm}$. The pressure in the Saturator was in the range of $4.5 \mathrm{kgf} / \mathrm{cm}^{2}$ to $6.0 \mathrm{kgf} / \mathrm{cm}^{2}$. At the surface loading rate of 30 $\mathrm{m}^{3} / \mathrm{m}^{2} \cdot \mathrm{hr}$, the saturator water level and pressure change experiments showed the most effective results at $38 \%$ water level and $5.5 \mathrm{kgf} / \mathrm{cm}^{2}$ pressure level, respectively. 


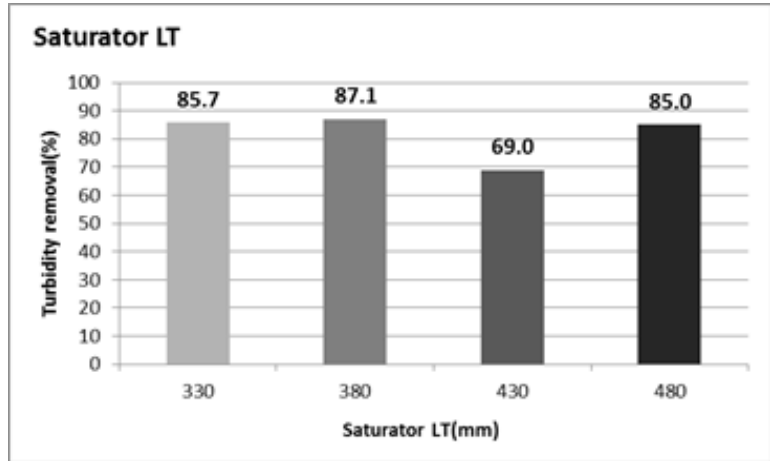

(a)

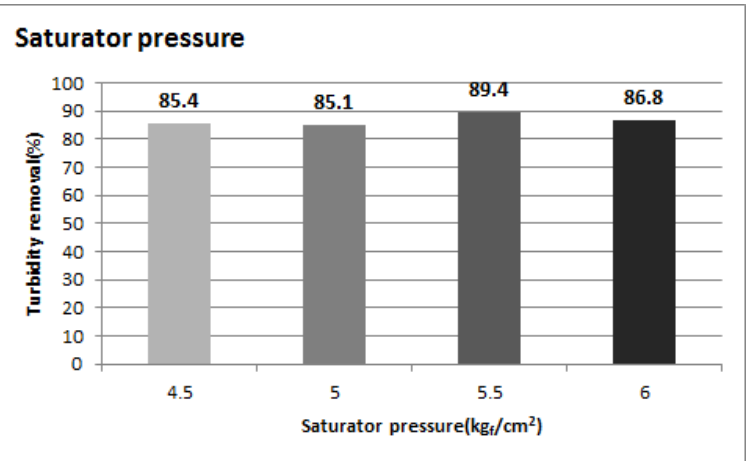

(b)

Fig. 3: Turbidity Removal Rate in High Rate DAF Pilot Plant by Saturator Water Level Change (a) and Saturator Pressure (b).

\subsection{Turbidity Removal Efficiency of High Rate DAF Pilot Plant ( $\left.500 \mathrm{M}^{3} / \mathrm{Day}\right)$}

High Rate DAF Pilot Plant (500 m³/d) was used for continuous operation from May 22, 2016 to May 24, 2017. As a result of the continuous operation, the surface loading rate and influent flow rate was about $30 \mathrm{~m}^{3} / \mathrm{m}^{2} \cdot \mathrm{h}$ and was about 27 $\mathrm{m}^{3} / \mathrm{hr}$, and the recycle rate of the DAF process was operated at 10 to $15 \%$. The turbidity of the DAF process was slightly decreased due to the influx of high turbidity water after June 27, 2016. However, turbidity of the treated water was less than 1.0 NTU. High rate DAF pilot plnat could be suitable process for the removal of turbidity. Turbidity results from continuous operation of High Rate DAF pilot plant under given conditions showed about $1.0 \sim 6.0$ NTU of influent and about $0.48 \sim 1.0 \mathrm{NTU}$ of treatment water.

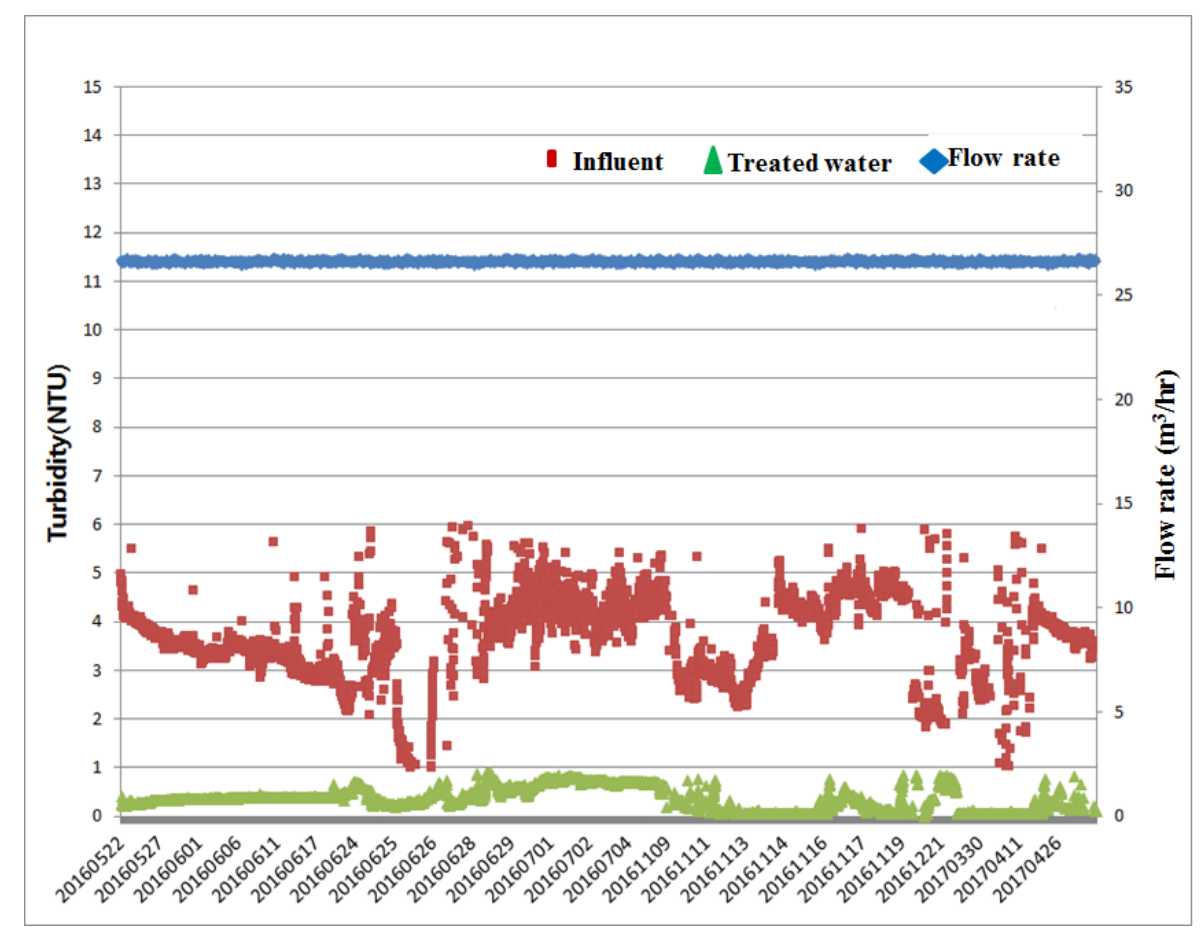

Fig. 4: Variation Flow Rate and Turbidity in the Raw and Treated Water during the Operation of DAF Pilot Plant.

Edzwald (2001) suggested that DAF has high removal efficiency of Cryptosporidium as much as the oocyst log removal of about 2.5 for spring and 1.7 for winter. Furthermore, Edzwald and co-workers found that DAF is very suitable for treating backwash water which may contain pathogenic agents and can be achieved the effluent water turbidity of below 1 NTU 
when the feed water turbidity was in excess of $50 \mathrm{NTU}$ [8]. Generally, the bubble size should be in the range of 10 to 120 $\mu \mathrm{m}$ to form stable bubble-floc aggregates and its mean diameter is about $40 \mu \mathrm{m}$. Strong and small size floc particles can be produced by strong flocculation mixing and short flocculation time. Since bubbles and particles need to be attached and particle-bubble agglomerate density should be reduced to less than water, large flocs are not necessary for flotation unlike for sedimentation [9]. Recently, flotation was combined with filtration in one tank in Sweden and other countries [10, 11].

\subsection{Evaluation of Algae Cell Counts by High Rate DAF Pilot Plant}

The efficiency of algae removal was evaluated through operation of a DAF combined process pilot plant (500 m3/d). As a result of the analysis of algae cell counts, it was found that the most of the algae species was diatoms which have been present from December of $2016[12,13]$. The number of algae species of raw water in the DAF pilot plant was estimated to be $100-120$ cells $/ \mathrm{mL}$ in the winter to spring season. In DAF treated water, the number of algae was detected to be less than 100 cells $/ \mathrm{mL}$. In particular, the total algae cell counts of the influent water 0n April 13, 2017 was 257 cells $/ \mathrm{mL}$, which was 27 cells $/ \mathrm{mL}$ in the DAF treated water, and the removal efficiency was about $90 \%$. As a result of the experiment on the source of the $\mathrm{Y}$ water treatment plant, the algae cell counts in the DAF treated water was analyzed to be less than 100 cells $/ \mathrm{mL}$, and it is expected that the DAF process is effective in removing the algae from the raw water.

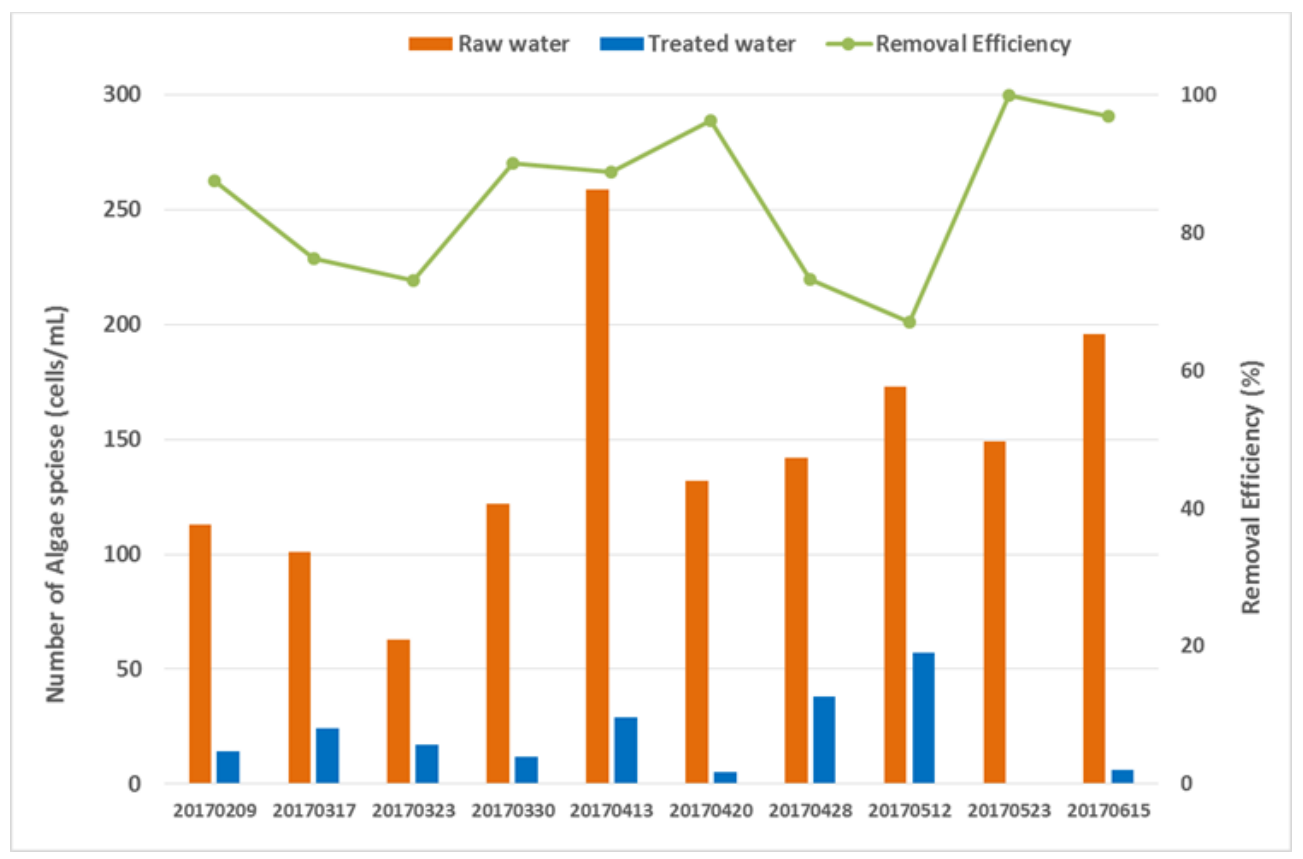

Fig. 5: Evaluation of Algae Cell Counts by High Rate DAF Pilot Plant

\section{Conclusion}

The results of experiments on the flocculant dose in the DAF pilot plant for the Y water treatment plant showed the most efficient results at the concentration of $10 \mathrm{mg} / \mathrm{L}$, however additional optimization experiment might be able to performed according to various raw water characteristics, At the surface loading rate of $30 \mathrm{~m} 3 / \mathrm{m} 2 \cdot \mathrm{hr}$, the saturator water level and pressure change experiments showed the most effective results at $38 \%$ water level and $5.5 \mathrm{kgf} / \mathrm{cm} 2 \mathrm{pressure}$ level, respectively. High rate DAF pilot plnat could be suitable process for the removal of turbidity. Turbidity results from continuous operation of High Rate DAF pilot plant under given conditions showed about $1.0 \sim 6.0$ NTU of influent and about $0.48 \sim 1.0 \mathrm{NTU}$ of treatment water. Also, the number of algae species of raw water in the DAF pilot plant was estimated to be $100-120$ cells $/ \mathrm{mL}$ in the winter to spring season. In DAF treated water, the number of algae was detected to 
be less than 100 cells $/ \mathrm{mL}$. As a result of the experiment on the source water of the $\mathrm{Y}$ water treatment plant, stable turbidity and algae removal possibility were confirmed while operating the DAF process under the condition of the surface loading rate of $30 \mathrm{~m}^{3} / \mathrm{m}^{2} \cdot \mathrm{hr}$.

\section{Acknowledgements}

This subject is supported by Korea Ministry of Environment (MOE) as "Algae monitoring and removed to utilized R\&D substantiation Project" (2015001800002) and "Global Top Project (2016002130001)"

\section{References}

[1] WHO, Cyanobacterial Toxins: Microcystin-LR Guidelines for Drinking-water Quality. Addendum to volume 2. World Heath Organization, Geneva, 1998.

[2] K. Sivonnen, G. Jones, Cyanobacterial toxins. In: I. Chorus, J. Bartram eds, Toxic Cyanobacteria in Water. A Guide to Their Public Health Consequences, Monitoring and Management, first ed. World Health Organization, 1999, pp. 41e91, E\& FN SPON, London.

[3] D. H. Kwak, H. J. Jung, S. J. Kim, C. H. Won and J.W. Lee, "Separation characteristics of inorganic particles from rainfalls in dissolved air flotation: A Korean perspective," Sep. Sci. Technol., vol. 40, pp. 3001-3015, 2005.

[4] M. R. Teixeira and M. J. Rosa, "Comparing dissolved air flotation and conventional sedimentation to remove cyanobacterial cells of Microcystis aeruginosa Part I. The key operating conditions," Sep. Purif. Technol., vol. 52, pp. 84-94, 2006.

[5] J. K. Edzwald and J. P. Walsh, "Dissolved Air Flotation: Laboratory and Pilot Plant Investigation," AWWA Research Foundation, Denver, CO, 1992.

[6] AWWA, Water Quality and Treatment, A Handbook of CommunityWater Supplies, fifth ed. McGraw-Hill, USA, 2000 .

[7] J. K. Edzwald, J. P. Walsh, G. S. Kaminski, H. J. Dunn, "Flocculation and air requirements for dissolved air flotation," J. Am. Water Works Assoc., vol. 84, no. 3, pp. 92-100, 1992.

[8] J. K. Edzwald et al, "Removal and fate of Cryptosporidium in dissolved air drinking water treatment plants," Water Science \& Technology, vol. 43, no. 08, pp. 51-57, 2001.

[9] H. Odegaard, "Optimization of flocculation/flotation in chemical wastewater treatment," Water Sci. Technol., vol. 31 no. 3-4, pp. 73-82, 1995.

[10] M. Krofta, L. K. Wang, "Development of innovative flotation filtration systems for water treatment Part A, First full-scale sand float plant in USA," Proceedings Water Reuse Symposium, Future III of water reuse, San Diego, 1984.

[11] L. R. Van Vuuren, F. J. de Wet, F. J., "Dissolved-air flotation-filtration studies in South Africa," A.W.W.A. Research Foundation News, Denver, Colorado, 10-12, 1984.

[12] H. S. Kim, S. J. Hwang, and D. S. Kong, "Cyanobacterial development and succession and affecting factors in a eutrophic reservoir," Korean J. Limnol., vol. 40, no. 1, pp. 121-129, 2007.

[13] C. M. Choi, J. H. Kim, W. I. Kim, J. S. Lee, G. B. Jung, J. T. Lee, S. G. Moon, "Phytoplankton Flora and Community Structure in the Lower Nakdong River," Korean J. Environ. Agric., vol. 26, no. 2, pp. 159-170, 2007. 